\title{
The Spatial Variation of Visitors of Beach Resorts in Banyuwangi Regency, East Java Province
}

\author{
M.H. Dewi Susilowati \\ Department of Geography \\ University of Indonesia \\ Depok, Indonesia \\ Corespending email: maria.hedwig@ui.ac.id \\ Oki Pratama \\ Department of Geography \\ University of Indonesia \\ Depok, Indonesia
}

\begin{abstract}
Banyuwangi Regency called the sunrise of Java. It is one of the favorites of tourism in East Java. Banyuwangi Regency has been awarded "12th UNWTO (United Nation World Tourism Organization) Awards" Inter- the location of beach attraction has different characteristic can cause differences in the number of visitors. The objective of research was the correlation between the number of visitors and the characteristics of location of beach attractions (primary facilities, secondary facilities, conditional facilities and accessibility). The method used are the spatial and statistical analysis (chi-square). The results showed correlation between the number of visitors and the characteristics of beach attraction. The correlation between variables indicate the value is $\mathbf{0 . 7 0 7}$ and significant at the significance level $(\alpha)=0.05$. Based on spatial analysis shows the most visitors are placed at the southern, especially the Pulau Merah, Plengkung dan Bangsring. Facilities at the three places are relatively the same as the other places, but it has advantages as a place of international activity such as International Surfing Competition (Pulau Merah), Quicksilver Pro Surfing Championship (Plengkung), Tabuhan Island Pro Kite Boarding Competition, Underwater Festival (Bangsring), impact to the number of visitors of the domestic and foreign tourists more than any other places.
\end{abstract}

Keywords - Characteristic, beach attraction, visitors.

\section{INTRODUCTION}

Indonesia is an archipelago country, which has many tourist objects beautiful and interesting place to be visited by foreign tourists. The tourism sector is the mainstay of Indonesia to add to the national economy. In the next five years, the government set a target of 20 million foreign tourists visit.

Tourism in Indonesia is an important economic sector in Indonesia. Based on data from the year 2014 the number of foreign tourists coming to Indonesia > 9.4 million or an increase of $7.05 \%$ compared to the year 2013 (Badan Pusat Statistik, 2015).

Natural and cultural resources is an important component of tourism in Indonesia. Indonesia has a tropical climate, 17,508 islands and the length of coastline are $99,000 \mathrm{~km}$ and have interesting attractions for domestic and foreign tourists.

Tourism has grown rapidly and become one of the world's leading economic phenomena. Tourism is used by many countries for economic development (Awang, et al., 2009; Deng, et al., 2002) Tourism used to development strategy for generating income, creating jobs and stimulating the economy (Sindiga, I. 1999)

The success of a tourist destination in the world market is influenced by the attractiveness and competitiveness of their (Enright \& Newton 2004). Tourism can play a role in the world market, depending tourist attraction developed, developed and managed properly (Gomezelj, D. O., \& Mihalič, 2007). The tourism sector is currently one of the leading sectors for the government of the Republic of Indonesia in obtaining foreign exchange (Pratama, Oki, 2016).

The development of tourism cannot be separated from the increasing number of tourist destinations and the development of the destination. Tourist destination has certain requirements in order to grow that has a diversity of attractions, availability of accessibility, and facilities as well as the convenience of tourists (Mill, 2000). Characteristics of the location is the foundation of the science of tourism, because the location must have facilities (Cho, 2008; Gunn, 1972). The number of tourists coming to the location are varied, according to the characteristics of the object.

Banyuwangi Regency has coastal tourist attractions to be visited by foreign and domestic tourists. The distance from one tourist spot to the other tourist attractions are varied (one $\mathrm{km}$ up to ten $\mathrm{km}$ ). Banyuwangi Regency called the sunrise of Java. It is one of the favorite of tourism in East Java. Banyuwangi Regency has been awarded "12th UNWTO (United Nation World Tourism Organization) Awards" Inter-beach attraction have different characteristic may cause differences in the number of visitors (Dinas Kebudayaan dan Pariwisata 
Kabupaten Banyuwangi, 2015 and 2016; UNWTO. 2015 and 2016).

The objective of research was the correlation between the number of visitors and the characteristics of location of beach attractions (primary facilities, secondary facilities, conditional facilities and accessibility).

\section{METHOD}

\section{A. Research framework}

Banyuwangi Regency has a variety of attractive beach resorts. The number of visitors varies according to the characteristics of location of beach attractions. (Table 1).

\section{B. Data collection}

The types and sources of data collected include: (1) the number of visitors the location of beach attraction in Banyuwangi; (2) the location of beach attraction (3) primary facilities include; site attraction and event attraction; (4) secondary facilities include; the number of hotels and lodging, restaurants, souvenir shop; (5) conditional facilities includes; public toilets, parking lot, worship place; (6) accessibility (road grade, road conditions, mode).

\section{Data processing}

Data processing includes: (1) classification of visitor data, facilities data classification (primary, secondary, conditional); (2) the spatial and tabular data processing technology with Geographic Information System (GIS); (3) quantitative data processed by SPSS (Statistical Product and Service Solutions).

\section{Data analysis}

Analysis of the data used is spatial analysis with a map overlay to assess the characteristics of beach attraction. Statistical analysis (chi-square) was used to determine correlation between the number of visitors and characteristics of the location of beach attraction. Contingency coefficient is used to determine the correlation value and tested by Chi Square (X2) test.

TABLE I. RESEARCH FRAMEWORK

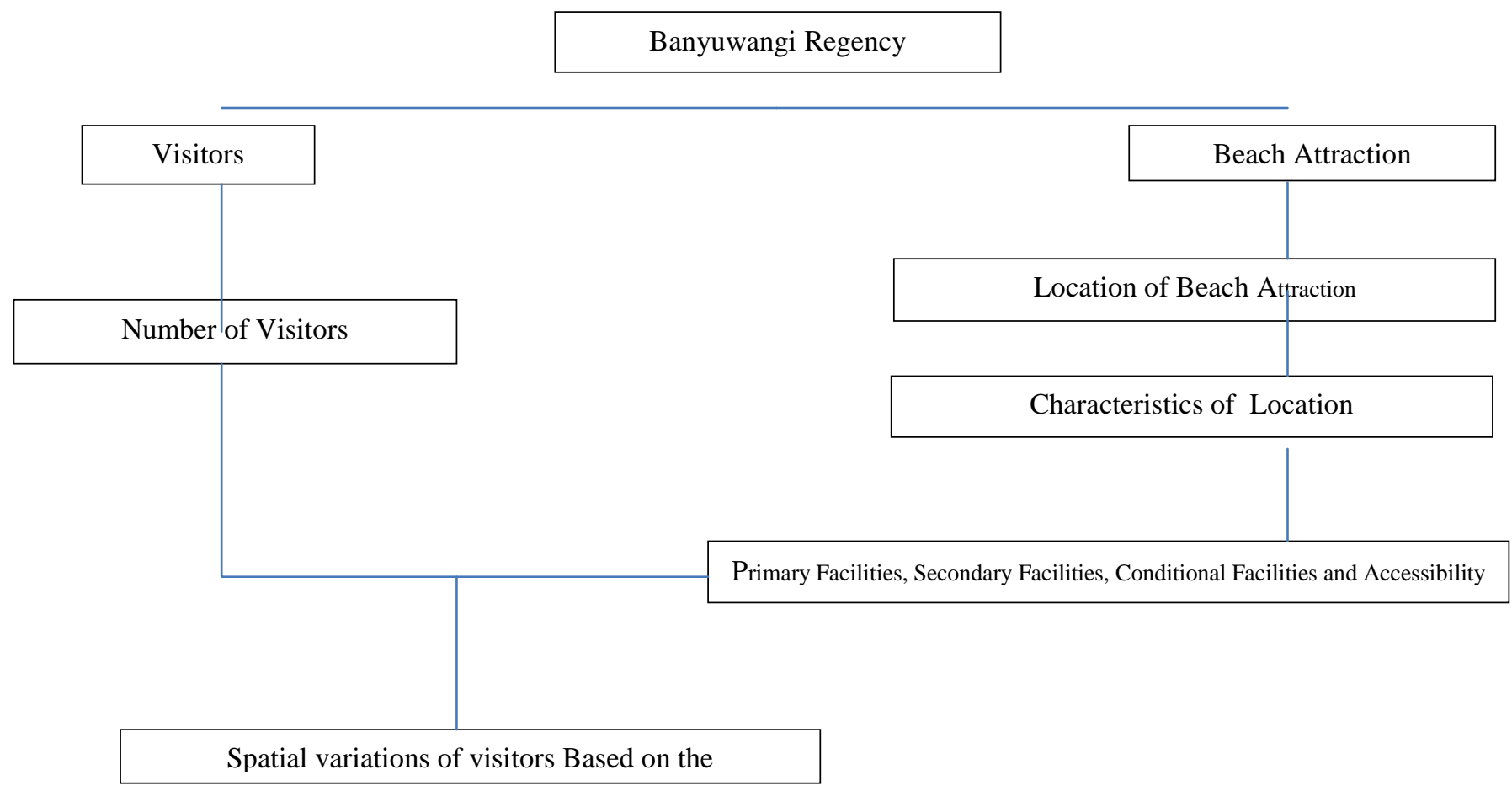




\section{FINDING AND DISCUSSION}

\section{A. Visitors variations}

The number of visitors in the beach of Banyuwangi Regency was varied at one place to another place. The most visitors were concentrated in the southern beach. Based on the results of surveys, the dominant types of travelers who visited attractions in Banyuwangi are tourists coming from Banyuwangi itself and from other areas such as Situbondo, Jakarta, Malang, Surabaya, Jember, and Bali. In addition, the number of foreign tourists who come just slightly compared with domestic tourists. Tourist visits occur especially on holidays or certain large and when the event Banyuwangi Festival.

Banyuwangi is a tourist destination that is still local and regional. Most visitors come from the Banyuwangi district and other areas in the territory of Indonesia. In 2012, the government is targeting foreign tourists that visit Banyuwangi, and since the year began many foreign tourists who come to visit Banyuwangi in particular at each point of the Triangle Diamond.

Based on the data in 2014 and 2015, the number of visitors at various Location of beach attractions in Banyuwangi Regency was increased. Tourist sites have the highest number of visitors is the Pulau Merah Beach, while the lowest is Parang Ireng.

Further analysis is to divide the number of visitor locations in Banyuwangi 2015 into three classes, with each class boundaries as follows:

- Low Class, has the number of visitors <130,000, covering Location of beach attractions of Kampe beach, Muncar beach, Mustika beach, Segara Anakan beach, Wedi Ireng beach, Grajagan Beach, Lampon Beach, Parang Ireng Beach, Parang Kursi Beach, Blimbingsari Beach, Rajegwesi beach, Watu Dodol, Teluk Hijau, Sukamade beach, and Boom beach.

- Medium Class, has a number of visitors 130000260000 include Location of beach attractions of Plengkung beach, and Bangsring beach.

- High Class, has a number of visitors > 260,000. Include Location of beach attractions Pulau Merah beach.

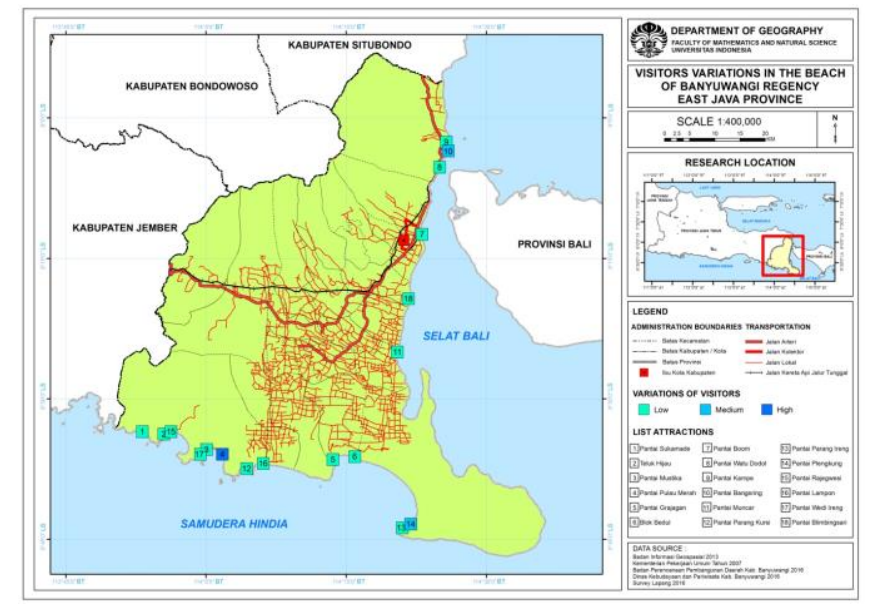

Fig. 1. Source: Pratama, Oki. 2016

\section{B. Facilities of Location}

- Primary facilities

Primary facilities are the attractions at each location of beach attractions include site attraction and event attraction. Site attraction is the natural attractions of the beach and a place of tourist activities. Location of beach attractions in Banyuwangi which has the highest attraction site is Watu Dodol beach. This location has five sites attraction, which consists of Watu Dodol beach, Batu Karang Watu Dodol, Gua Japan, and Sumur Air Tawar. Locations which have little attraction site which is contained in Parang Kursi Beach and Parang Ireng Beach, with each only have one site attraction.

While the event attraction of location of beach attraction in Banyuwangi which has an event, attraction is the beach Bangsring, Watu Dodol, Boom Beach, Muncar beach, Pulau Merah Beach, Rajegwesi beach and Lampon Beach. Boom beach has an event the highest attraction in Banyuwangi. Event attraction is that the Gandrung Sewu Festival, Banyuwangi Jazz Beach Festival, Green and Recycle Fashion Week, Banyuwangi Kite Festival, Barongan Nusantara Festival.

- Secondary facilities

The secondary facilities are a support component for tourists to be more varied in determining the choice of visiting the location of beach attraction. Secondary facilities include accommodation, restaurants, and a souvenir shop. Accommodation facilities are most numerous in type Boom Beach and Pulau Merah Beach. Location of the Boom Beach is located in the city center, so that the development process more quickly than elsewhere. Pulau Merah Beach has a number of the same accommodation with the Boom Beach as well as the number of souvenir shops is the biggest. Blimbingsari Beach has the highest number of restaurants for culinary region is the main attraction of the Blimbingsari Beach. 
- Conditional facilities

Conditional facilities is tourism infrastructure facilities, such as toilets, parking lots and places of worship. Generally, facility conditional on the location of beach attraction in Banyuwangi can be said to be complete, although at some point the facility is located quite far.

- Accessibility

According to Burton (1995), accessibility cannot be separated by the availability of transport systems: (1) Transportation of transport such as cars, buses, trains, aircraft; (2) The road network such as roads, railways, airlines.

Accessibility to the location of beach attraction in the District can be reached by an overland route. Local road conditions with the asphalt surface. Some locations such as; Wedi Ireng beach, the Green Bay, Parang Kursi beach, Parang Ireng beach, Sukamade beach have any kind of soil surface, because the location is remote and requires to tracking before arriving at that location. The road to Green Bay and Sukamade beach is not good, because of the condition of the morphology of the steep, sharp turns as well as the rise.

\section{Characteristics of The Location of Beach Attractions}

Characteristics of location of beach attraction is the potential that drives tourists to a location. Characteristic of the location of beach attraction facilities obtained from the assessment of primary, secondary facilities, conditional facilities and accessibility. The primary facility consists of site attraction and event attraction. Secondary views of accommodation facilities, restaurants, and souvenir shops are all around location. Conditional facilities consists of toilet, places of worship, and a parking lot. whereas the accessibility consists of a public transportation route type and road class.

Based on calculations indicate characteristics Pulau Merah Beach is a location that has the highest value of the characteristic (complete) than the other location with a value of 5.298 completeness. While the value of the lowest characteristic is Parang Ireng beach the completeness value of 0.595 . Of the value of the characteristics obtained, then will be classified into three classes, namely high, medium, and low. Limitations in each class as follows:

- Low Class, has a value of $<2.2$, include Parang Ireng beach, Parang Kursi beach, Wedi Ireng beach, Lampon beach, Kampe beach, Sukamade beach, Rajegwesi beach;

- Medium Class, has a value of 2.2 to 3.7 include Bangsring beach, Mustika beach, Muncar beach, Green Bay, Grajagan Beach, Plengkung beach, Segara Anakan, Blimbingsari beach;

- High Class, has a value. > 3.7, include Boom Beach, Watu Dodol beach, Pulu Merah Beach.

\section{The relationship between characteristics of location and Visitors}

Based on spatial analysis with an overlay map shows that most tourists visit the place which with facilities are complete and high accessibility. Based on spatial analysis shows the most visitors are placed at the southern, especially the Pulau Merah, Plengkung dan Bangsring. Amenities at the three places are relatively the same as the other places, but its have advantages as a place of international activity such as International Surfing Competition (Pulau Merah), Quicksilver Pro Surfing Championship (Plengkung), Tabuhan Island Pro Kite Boarding Competition, Underwater Festival (Bangsring), impact to the number of visitors of the domestic and foreign tourists more than any other places.

Based on statistical analysis by chi-square analysis (Table 1 and 2) shows a correlation value or the Contingency Coefficient $(\mathrm{CC})$ between the variable characteristics of the location of beach attraction and the number of visitors was 0.707 and Chi-Square value 18.000 (the significance level $(\alpha)$ $=0.05$ ).

TABLE II. CHI-SQUARE TESTS

\begin{tabular}{|l|l|l|l|}
\hline & Value & Df & Asymp. Sig. (2-sided) \\
\hline Pearson Chi-Square & $18.000^{\mathrm{a}}$ & 4 & .001 \\
Likelihood Ratio & 16.220 & 4 & .003 \\
Linear-by-Linear & 8.725 & 1 & .003 \\
Association & 18 & & \\
N of Valid Cases & 18 & & \\
\hline
\end{tabular}

Source: Alhusin, Syahri, 2003

a. 7 cells $(77.8 \%)$ have expected count less than 5 . The minimum expected count is 17 .

TABLE III. SYMMETRIC MEASURES

\begin{tabular}{|l|l|l|}
\hline & Value & Approx. Sig. \\
\hline $\begin{array}{l}\text { Nominal } \\
\text { Nominal }\end{array}$ & $\begin{array}{c}\text { by Contingency } \\
\text { Coefficient }\end{array}$ & .707 \\
N of Valid Cases & 18 & .001 \\
\hline
\end{tabular}

\section{CONCLUSIONS AND SUGGESTIONS}

Spatial variation of visitors showed by the most visitors are placed at the southern, especially the Pulau Merah, Plengkung dan Bangsring. Amenities at the three places are relatively the same as the other places, but it has advantages as a place of international activity such as International Surfing Competition (Pulau Merah), Quicksilver Pro Surfing Championship (Plengkung), Tabuhan Island Pro Kite Boarding Competition, Underwater Festival (Bangsring), impact to the number of visitors of the domestic and foreign tourists more than any other places. 
The correlation between variables of the visitors number and characteristics of the location of beach attraction indicate the value is 0.707 and significant at the significance level $(\alpha)=$ 0.05 .

\section{REFERENCES}

[1] Awang, K, W, Hassan, W.M. \& Zahari, M.S, 2009, "Tourism Development; A Geographical Perspective". Asian Social Science, vol 5 (5), pp. 67-76.

[2] Alhusin, S, 2003. "Aplikasi Statistik Praktis dengan SPSS for Window", Graha Ilmu, Yogyakarta.

[3] Central Bureu of Statistic, 2015, "Pariwisata: Jumlah Kedatangan Wisatawan Mancanegara ke Indonesia Menurut Pintu Masuk", $1997-$ 2014, http://www.bps.go.id/linkTabelStatis/view/id/1387, 13 Januari 2016 (15.22 WIB).

[4] Statistical Bureu of Banyuwangi District, 2015, "Kabupaten Banyuwangi dalam Angka Tahun 2015", Statistical Bureu of Banyuwangi District, Banyuwangi

[5] Burton, R, 1995, "Travel Geography”, Pitman Publishing, London.

[6] Cho, V, 2008, "Linking location attractiveness and tourist intention", Tourism and Hospitality Research, vol (8), pp. 220-224.

[7] Deng, J, King, B, \& Bauer, T, 2002, "Evaluating Natural Attraction for Tourism", Annals of Tourism Research, vol. 29 (2), pp. 422-438.

[8] Department of Culture and Tourism Banyuwangi District, 2015, "News: Badan Pariwisata PBB (UNWTO) Menjadikan Banyuwangi Nominator Penghargaan Pariwisata", http://banyuwangitourism.com/news/badan-pariwisata-pbb-unwtomenjadikan-banyuwangi-nominator-penghargaan-pariwisata.html, 18 Januari 2016 (12.45 WIB).

[9] Department of Culture and Tourism Banyuwangi District, 2016, "News: Banyuwangi Raih Penghargaan Pariwisata Dunia", http://banyuwangitourism.com/news/banyuwangi -raih-penghargaanpariwisata-dunia.html, 9 Februari 2016 (12.10 WIB).

[10] Department of Culture and Tourism Banyuwangi District, 2016 , "News: Inovasi Daerah di Presentasikan di Dunia", http://banyuwangitourism.com/news/inovasi-daerah-di-presentasikandi-dunia.html, 9 Februari 2016 (11.33 WIB).

[11] Enright, M. J, \& Newton, J, 2004, “Tourism Destination Competitiveness: A Quantitative Approach". Tourism Management vol. 25: 777-788

[12] Gomezelj, D. O, \& Mihalič, T, 2007, "Destination competitiveness Applying different models, the case of Slovenia", Tourism Management, vol. 29, pp. 294-307.

[13] Gunn, C. A, \& Var, T, 2002, “Tourism Planning: Basics Concept Cases", 4th Edition, Routledge, New York and London.

[14] Klein, Y., Osleeb, J, \& Viola, M, 2004, "Tourism-Generated Earnings in the Coastal Zone: A Regional Analysis". Journal of Coastal Research vol. 20 (4), pp. 1080-1088.

[15] Moscardo, G, 2001, "Visitor Evaluations of Built Tourist Facilities: Pontoons on The Great Barrier Reef', Journal of Tourism Studies vol. 12 (1), pp. 28-38.

[16] Mill, R. C, 2000, “Tourism, The International Busines", Penerbit Raja Grafindo, Jakarta.

[17] Pratama, Oki, 2016, "Tingkat Daya Tarik Objek Wisata Pantai di Kabupaten Banyuwangi", Skripsi, Departemen of Geography Indonesia University.

[18] Sindiga, I, 1999, "Tourism and African Development; Change and Challenge of Tourism in Kenya", Ashgate, Hampshire.

[19] UNWTO, 2015, "Content: 12th UNWTO Awards Finalists", http://know.unwto.org/content/ 12th-unwto-awards-finalists, 18 Januari 2016 (14.33 WIB).
[20] UNWTO, 2016, "Content: 12th UNWTO Awardees", http://know.unwto.org/content/12th-unwto-awardees, 9 Februari 2016 (12.25 WIB) 